\title{
Escaping the debt constraint on growth: a suggested monetary policy for Brazil
}

\author{
Fugindo da restrição da dívida ao crescimento: \\ uma política monetária sugerida para o Brasil
}

THOMAS I. PALLEY*,**

RESUMO: As taxas de juros existentes implicam dinâmicas de dívidas explosivas para o Brasil. Ele também enfrenta inflação crescente das depreciações cambiais anteriores, o que poderia provocar uma depreciação futura. Essas condições impõem uma contradição política. O Brasil precisa de taxas de juros menores para a sustentabilidade da dívida, mas uma política monetária rígida para evitar a depreciação da taxa de câmbio e a inflação. $\mathrm{O}$ artigo desenvolve uma estratégia para escapar dessa contradição. A política deve reforçar a confiança dos investidores para reduzir as taxas de juros externas, reduzir as taxas de juros domésticas para reduzir os encargos do serviço da dívida e implementar controles internos de criação de crédito para controlar a inflação.

PALAVRAS-CHAVE: Armadilha da divida; taxas de juros; taxas de câmbio, Brasil.

ABSTRACT: Existing interest rates imply explosive debt dynamics for Brazil. It also faces rising inflation from earlier currency depreciations, which could trigger future depreciation. These conditions impose a policy contradiction. Brazil needs lower interest rates for debt sustainability, but tight monetary policy to avoid exchange rate depreciation and inflation. The paper develops a strategy to escape this contradiction. Policy must bolster investor confidence to lower external interest rates, lower domestic interest rates to reduce debt service burdens, and implement domestic credit creation controls to control inflation.

KEYWORDS: Debt trap; interest rates; exchange rates; Brazil.

JEL Classification: E40; E44; F30; F40.

\footnotetext{
* Director, Globalization Reform Project, Open Society Institute, Washington/DC, USA. E-mail: tpalley @osi-dc.org. Submitted: January 2003; accepted: March 2003.

$* *$ The views expressed in this paper are those of the author and do not reflect the views of the Open Society Institute.
} 


\section{BRAZIL'S MACROECONOMIC POLICY AT A CROSSROADS}

Taking office in January 2003, President Lula da Silva inherited a difficult economic situation marked by great uncertainty following the financial crisis of 2002. Fortunately, in the first six months of the new president's term, financial markets have responded positively. The Real has rebounded from its crisis overshoot, and the strength of Brazil's currency and stock market is being interpreted as a sign that current macroeconomic policy is working. To some, the implication is that Brazil only needs to stay the course with its existing regime of tight money.

This paper argues that this position is mistaken, and that the existing policy configuration cannot achieve economic growth. At best, it can ensure financial stability. However, more likely, it will result in stagnation that is ultimately joined by renewed financial crisis. Instead, Brazil must adopt a new monetary policy mix that enables it to escape the debt constraint on growth. Analytically, this constraint can be understood through the highly indebted developing country trilemma which has countries grappling to control the exchange rate and external interest rate, the domestic inflation rate, and debt sustainability. Escaping the trilemma calls for an external financial strategy that bolsters investor confidence, domestic credit creation controls that keep the lid on inflation, and lower domestic interest rates that ensure debt sustainability.

Turning to specifics, the recent strength of the Real is a welcome development, and one that the paper is supportive of - provided it does not go too far. But that strength must be capitalized upon. At this stage, the strong real should be used as occasion to twist Brazil's debt structure by reducing the extent of foreign currency denominated and indexed debt, and replacing it with pure domestic debt. In addition, domestic interest rates must be brought down. Absent this, Brazil's economy stands to be impaled by the twin forces of a strengthening exchange rate and a high cost of capital. The former stands to reduce exports, raise imports, and undermine investment by lowering manufacturing profitability: the latter stands to compound investment spending weakness by imposing too high a required rate of return.

Finally, in twisting the debt structure and lowering domestic interest rates, there remains the persistent danger of inflation. Higher inflation could derail the proposed policy shift by causing renewed currency weakness. This would raise the domestic currency burden of Brazil's foreign currency linked debts, inflicting damage on both the public and private sectors. The recent strength of the Real has reduced inflation pressures, creating an opportune moment for initiating a changed stance of monetary policy. However, to the extent that inflationary fears persist, the paper recommends adoption of a new form of credit regulation based on asset based reserve requirements. Such regulation can control inflation without recourse to high domestic interest rates, thereby enabling Brazil to have low inflation, a stable currency, and domestic economic expansion. 


\section{OUTLINE OF THE PAPER}

The argument for the proposed new policy configuration is developed in stages. Section III focuses on the problem of debt instability, which persists despite the current strength of the Real and stock market. Brazil's implied debt dynamics cannot be solved by additional fiscal austerity and a higher primary budget surplus. ${ }^{1}$ Instead, additional austerity risks compounding existing domestic demand weakness, while not tackling the root problem of excessively high interest rates.

Section IV describes the composition of Brazil's public debt, which is both foreign and domestic currency denominated. In addition, there are significant private sector foreign currency debts. Section $\mathrm{V}$ then explores the policy contradiction imposed by Brazil's debt composition. On one hand Brazil needs lower interest rates to restore debt sustainability, but on the other hand it needs tight money to guard against a vicious cycle of exchange rate depreciation and inflation. This contradiction points to the need for a coordinated external and internal financial strategy. The external strategy must bring down the cost of foreign borrowing, while maintaining confidence in the exchange rate. The internal strategy must lower domestic interest rates, while keeping the lid on inflation.

Section $\mathrm{V}$ then develops a multiple equilibrium model of international financial markets, and argues Brazil is trapped in the bad high interest rate equilibrium. Section VI builds on this analysis, and develops an external financial strategy for escaping the pull of this bad equilibrium. Section VII then turns to the development of an internal financial strategy for lowering domestic interest rates. The combined external-internal financial strategy mix can be viewed as a means of escaping the highly indebted developing country trilemma whereby countries grapple to control the exchange rate and external interest rate, the domestic inflation rate, and debt sustainability.

\section{THE ALGEBRA OF DEBT INSTABILITY}

The unsustainability of Brazil's existing financial condition can be seen through a simple model of debt algebra. Such a model shows that existing real interest rates imply an exploding trajectory for the debt-to-GDP ratio that must eventually lead to default. The growth of the debt-to-GDP ratio is given by

$$
\mathrm{gD} / \mathrm{Y}=\mathrm{gD}-\mathrm{gY}
$$

where $\mathrm{g}_{\mathrm{D} / \mathrm{Y}}=$ growth of debt to income ratio, $\mathrm{g}_{\mathrm{D}}=$ growth of debt, and $\mathrm{g}_{\mathrm{Y}}=$ growth of real GDP. The growth of the debt is given by

\footnotetext{
${ }^{1}$ However, there is a case for fiscal reform to remedy perverse inequities, to free up funds for spending on high social priorities, and to set the stage for better management of the budget over the full course of the business cycle.
} 


$$
g_{D}=i+d / D
$$

where $\mathrm{i}=$ real interest rate on debt, $\mathrm{d}=$ primary budget deficit, and $\mathrm{D}=$ national debt. This can in turn be written as

$$
\mathrm{g}_{\mathrm{D}}=\mathrm{i}+[\mathrm{d} / \mathrm{Y}] .[\mathrm{Y} / \mathrm{D}]
$$

where $\mathrm{d} / \mathrm{Y}=$ primary budget deficit as a percent of GDP, and $\mathrm{Y} / \mathrm{D}=\mathrm{GDP}$ to debt ratio. Substituting (3) in (1) yields

$$
\mathrm{g}_{\mathrm{D} / \mathrm{Y}}=\mathrm{i}+[\mathrm{d} / \mathrm{Y}] \cdot[\mathrm{Y} / \mathrm{D}]-\mathrm{g}_{\mathrm{Y}}
$$

For the case of Brazil $\mathrm{i}=18 \%, \mathrm{~d} / \mathrm{Y}=-3.75 \%, \mathrm{Y} / \mathrm{D}=1.67$, and $\mathrm{g}_{\mathrm{Y}}=3.5 \%$. If the debt-to-GDP ratio is to be stabilized (i.e $\mathrm{g}_{\mathrm{D} / \mathrm{Y}}=0$ ), the real interest rate must fall to $9.75 \%$. If real GDP growth falls to $2 \%$, then the real interest rate must fall to $8 \%$.

The above simple debt - GDP algebra reveals that Brazil's problem is one of excessively high interest rates. Brazil has a primary budget surplus, a reasonable real growth rate, and a debt-to GDP ratio that is still within sustainable bounds. The one parameter that is out of balance is the interest rate. Given current real interest rates of $12 \%$ and an optimistic projected growth rate of $3.5 \%$, the primary budget surplus must rise to $5.1 \%$ of GDP just to maintain the existing debtto-GDP ratio. Yet, such a level of surplus will likely trigger economic stagnation, and it also risks engendering adverse political consequences from the implied cuts in government spending. In other words, sticking with the current policy may yield short term financial stability, but it is unlikely to generate economic growth and it also stands to be joined later by renewed financial instability.

\section{THE COMPOSITION OF BRAZIL'S DEBT: WHY BRAZIL CANNOT IGNORE INTERNATIONAL FINANCIAL MARKETS}

The above analysis of Brazil's debt dynamics makes no distinction between internal and external debt. This raises the question of whether Brazil can pursue a "go it alone" policy that disregards international financial markets. With its debt purely domestic in character, Brazil would be able unilaterally to use domestic monetary policy to lower interest rates - just as the U.S. has done. However, Brazil's debt is a complicated mix of conventional domestic currency denominated debt, domestic currency debt that is indexed to the exchange rate, and foreign currency denominated debt. These features mean that the exchange rate and the confidence of international investors are critical for the success of monetary policy. In effect, Brazil is handcuffed by external constraints, and hence the necessity of an external strategy.

Table 1 shows the composition of Brazil's public debt. ${ }^{2}$ Brazil's public debt-

\footnotetext{
${ }^{2}$ Debt figures are based on "Brazil - Letter of Intent: Memorandum of Economic and Financial Policies, and Technical Memorandum of Understanding” June 5, 2002 signed with the IMF (available at http:// www.imf.org/external/NP/LOI/2002/bra/02index.htm).
} 
toGDP ratio stands at $60 \%$. Of this total, $40 \%$ is traditional domestic currency denominated debt, $30 \%$ is domestic currency debt that is indexed to the exchange rate, and $30 \%$ is foreign currency denominated debt. This means that $60 \%$ of the total public debt is affected by the exchange rate, and $70 \%$ of the debt has its interest rate determined by domestic market rates. Hence, the need for an internal and external interest rate strategy.

Table 2 shows the composition of Brazil's external debt. The total value of external debt is $\$ 210$ billion or $41 \%$ of GDP. ${ }^{3}$ Of this total foreign debt, $45 \%$ is attributable to public sector borrowing and $55 \%$ is attributable to private sector borrowing. The significance of this is that both the public and private sectors stand to be negatively impacted by exchange rate depreciation.

Table 1: Decomposition of Brazil's public debt

\begin{tabular}{lcc}
\hline & $\%$ of GDP & Share of public debt \\
\hline Conventional domestic currency debt & $23.5 \%$ & $40 \%$ \\
Exchange rate indexed domestic currency debt & $18.0 \%$ & $30 \%$ \\
Foreign currency denominated debt & $18.5 \%$ & $30 \%$ \\
Total public debt & $60.0 \%$ & $100 \%$ \\
\hline
\end{tabular}

Source: IMF Letter of Intent, June 5, 2002 and author's calculations.

Table 2: Decomposition of Brazil's external debt

\begin{tabular}{lccc}
\hline & U.S. dollars $\%$ & of GDP & Share of external debt \\
\hline Public sector external debt & \$95 billion & $18.5 \%$ & $45 \%$ \\
Private sector external debt & $\$ 115$ billion & $22.5 \%$ & $55 \%$ \\
Total external debt & $\$ 210$ billion & $41.0 \%$ & $100 \%$ \\
\hline
\end{tabular}

Source: IMF Letter of Intent, June 5, 2002 and author's calculations.

\section{POLICY IMPLICATIONS: WHY BRAZIL MUST WATCH INFLATION AND THE EXCHANGE RATE}

The composition of Brazil's debt has critical policy implications. The large amount of foreign and exchange rate indexed debt means that investor confidence is critical. If investors lose confidence and exit, this will cause immediate large exchange rate depreciation that impacts both the public and private sectors. Regarding the public sector, it will cause an increase in the burden of the foreign

\footnotetext{
${ }^{3}$ Given the sharp depreciation of the Brazilian real over the second half of 2002, the foreign debt has likely increased as a share of GDP.
} 
currency denominated public debt, and it will also increase that part of the domestic currency denominated public debt that is indexed to the exchange rate. For the private sector, it will increase the burden of foreign currency denominated borrowings. Private sector firms located in the export sector would be protected as their earnings are denominated in foreign currency terms. However, private sector firms producing for the domestic market and which have borrowed abroad to finance the purchase of imported capital goods could face bankruptcy.

In addition to these negative "balance sheet" impacts, exchange rate depreciation would have negative "inflation" impacts owing to exchange rate pass-through. Increased inflation would be economically deleterious for several reasons. First, inflation is bad for working people. Money is an important store of value for the poor, and the value of money is eroded by inflation. Second, wage increases tend to lag inflation, so that rising inflation effectively lowers real wages. Third, inflation makes lenders less willing to lend long, and therefore tends to undermine the market for long term finance. This is a market that Brazil needs to develop, and undermining it runs counter to Brazil's development goals. Fourth, higher inflation stands to cause further exchange rate weakness to the extent that investors sell Brazil's currency to avoid being saddled with depreciation losses, thereby engendering more pass-through inflation and also raising the burden of foreign currency denominated debts.

This inflation, debt burden, exchange rate nexus is illustrated in Figure 1. Effectively there is a danger of a vicious cycle, with exchange rate depreciation triggering rising inflation and increased debt burdens, and rising inflation and higher debt burdens then spurring further exchange rate depreciation. These conditions imply a policy contradiction. On one hand, Brazil needs lower interest rates to restore debt sustainability, yet on the other hand it needs tight monetary policy and high interest rates to head off a vicious cycle of exchange rate depreciation and inflation.

Figure 1: Brazil's inflation, debt burden, exchange rate nexus

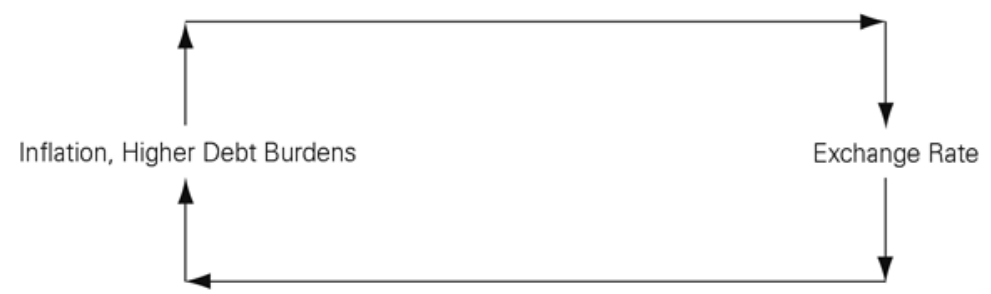

To escape this contradiction, the paper develops an unorthodox two part monetary strategy. The external component of the strategy focuses on escaping a high interest rate equilibrium trap in international financial markets through new measures to instill investor confidence. Moreover, the strengthening of the Real in the first half of 2003 provides the perfect platform from which to implement these new policies. The internal component of the strategy lowers domestic interest rates to reduce the burden of servicing the public debt, while imposing domestic credit 
creation controls to prevent a resurgence of inflation that could undermine investor confidence and trigger exchange rate depreciation.

\section{BRAZIL AND INTERNATIONAL FINANCIAL MARKETS: A PROBLEM OF MULTIPLE EQUILIBRIUM ${ }^{4}$}

Brazil's foreign interest rate problem can be interpreted in terms of a model of multiple equilibria, with Brazil now being stuck in the bad equilibrium with high interest rates. Because interest rates are high, investors expect a greater likelihood of Brazilian default, and because they hold such expectations they need a high interest rate to compensate them for bearing the risk of default. In this fashion, expectations sustain the bad equilibrium. The policy challenge is how to move financial markets from the "bad" high interest rate equilibrium to the "good" low interest rate equilibrium.

A formal model of multiple equilibria is developed in the appendix. Figure 2 displays a graphical analogue of the model. The horizontal axis displays the domestic market interest rate (i), while the vertical axis displays the return on foreign investments $\left(1+\mathrm{i}^{*}+\mathrm{z}\right)$ and domestic financial investments $(\mathrm{E}(\mathrm{R}))$. The risk adjusted return on foreign investments is described by the horizontal line equal to 1 $+i^{*}+z$. The non-linear wave function, $E(R)$, describes the expected return on domestic Brazilian bonds. In equilibrium the expected return on Brazilian domestic financial investments must equal the risk adjusted return in global markets.

The expected return function is highly non-linear with respect to the domestic interest rate, and Figure 2 shows the case where it partakes of a wave motion. Initially, a higher domestic interest rate raises the expected return on Brazilian assets. However, as interest rates rise, this pulls down the expected return owing to increased bankruptcy risk from higher debt service burdens. As the interest rate continues to rise, the expected return function may increase, perhaps because government moves to increase the primary surplus. But further rises in the interest rate then bring about a decline in the expected return as unstable debt dynamics kick in.

There are four equilibria in Figure 2. Equilibrium A is the stable "good" equilibrium with low interest rates. Equilibrium $\mathrm{B}$ has a low interest rate but is unstable. Equilibrium $\mathrm{C}$ is the stable "bad" equilibrium with high interest rates, and equilibrium $\mathrm{D}$ is the unstable high interest rate equilibrium. Brazil can be thought of as trapped in the bad high interest rate equilibrium given by $\mathrm{C}$ or $\mathrm{D}$. The policy challenge is to move the economy to A.

\footnotetext{
4 This section is based on the model presented in Palley (2002). That model is derived from the description of Brazil's.
} 


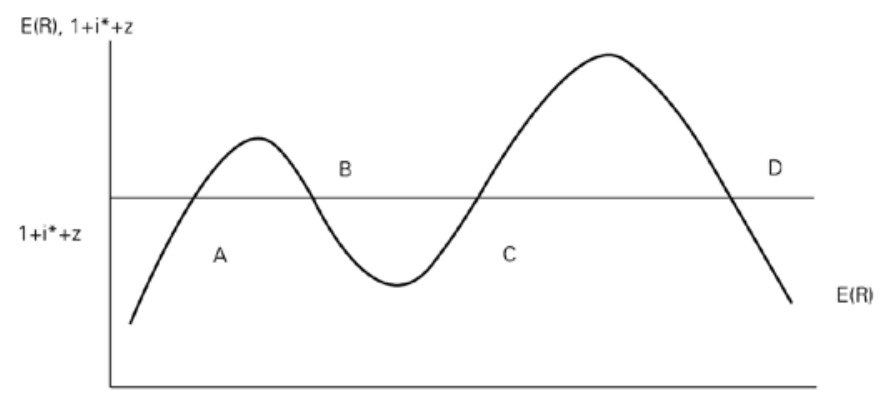

Domestic interest rate

Figure 3: Effect of a rise in foreign interest rates which can shift the economy from the good to the bad equilibrium

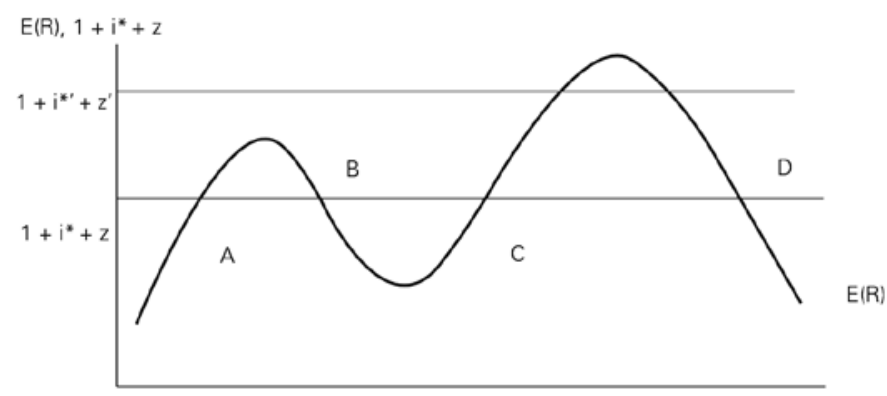

Figure 3 shows how exogenous shocks originating in the global financial center can negatively impact periphery countries such as Brazil. In Figure 3 the external interest rate increases, perhaps as a result of tightening of monetary policy in the U.S. by the Federal Reserve. If the tightening is sufficiently strong, a developing country could potentially be driven from the good low interest rate equilibrium at A to the bad high interest rate equilibrium at C. An interesting feature is that when rates in the center come down again, the developing country remains trapped in the bad equilibrium.

This scenario can reasonably be interpreted to apply to Brazil. In 1997 the East Asian financial crisis caused an increase in the risk premium, $\mathrm{z}$, demanded by global investors. This in turn shifted up the required rate of return $\left(i^{*}+\mathrm{z}\right)$, though this shift was mitigated by the Federal Reserve's lowering of rates to counter the crisis. The Fed's actions helped keep the U.S. economic boom going, but they also meant that subsequently (July 1999) the Fed started raising interest rates, thereby driving up the externally available interest rate, $\mathrm{i}^{*}$. Moreover, these adverse developments were compounded by appreciation of the U.S. dollar during this period. This caused Brazil's national debt to increase since much of it is either dollar denominated or 
indexed to the dollar. In effect, dollar appreciation served to push the $E(R)$ function down, compounding the effect of investors' rising required rate of return.

\section{AN EXTERNAL MONETARY STRATEGY TO ADDRESS BRAZIL'S EXTERNAL DEBT PROBLEM}

The above multiple equilibrium interpretation identifies Brazil's predicament. The challenge is how to bring down external interest rates. George Soros (2002) has proposed that the IMF issue some form of price guarantee to holders of Brazilian debt.

"The challenge would be how to bring interest rates down to that level.

That might require some international credit enhancements or guarantees, and the task would be to find the right instruments that keep the real risks as distinct from moral hazard within tolerable bounds (Financial Times, August 13, 2002.)

This would have the effect of increasing the expected return to Brazilian debt, reducing perceived default risk. In terms of the model, it would shift up the $E(R)$ function as is illustrated in Figure 4.

A second Soros suggestion is that the central banks of center countries accept Brazilian government paper at their discount windows (On Globalization, p. 136). In terms of the above model, it would have the effect of shifting up the $E(R)$ function. The reason is that it would increase the perceived liquidity of Brazilian paper to international investors since they would be able to use such paper as collateral at pre-set prices with center country central banks.

Figure 4: Effect of an increase in the default payment which shifts up the $E(R)$ function and can shift the economy to the good equilibrium

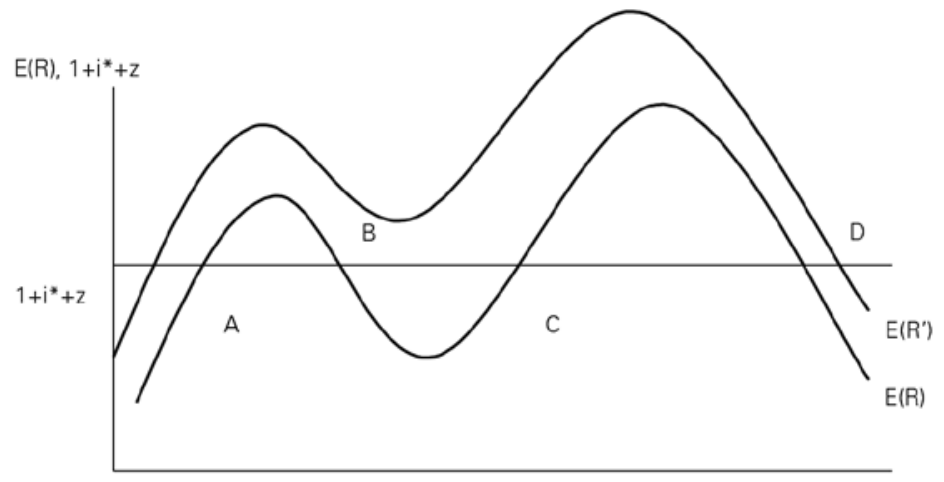

Another idea that has been proposed by Lerrick and Meltzer (2001), in connection with the discussion surrounding bailouts, is that the IMF should set 
a floor to the price of country debt. In times of crisis, rather than bailing out countries, the IMF would establish a facility allowing countries to buy their own debt at the deeply discounted floor price. This would provide support to bond prices, set a ceiling on interest rates, help retire part of a country's debt at below par prices, and give collateral to the IMF in the form of an asset traded on financial markets rather than the un-tradable promise of repayment it currently gets.

The Lerrick-Meltzer proposal is intended to provide an alternative orderly means of handling financial crises. However, in a multiple equilibrium model a similar mechanism can be used to free economies from the pull of a bad equilibrium before a crisis has taken hold. An announced guarantee floor price would effectively increase the value of the default state payment, thereby raising the $E(R)$ function. By simply setting up a facility to support an announced guaranteed floor price for Brazilian bonds, the IMF could potentially free Brazil from the high interest rate equilibrium in which it is trapped. In a world of expectations driven multiple equilibria, this might even be accomplished without actually buying any bonds.

The above arguments identify high interest rates as the cause of Brazil's financial crisis, with high interest rates driving a process of unsustainable debt dynamics. These debt dynamics have also impacted Brazil's exchange rate dynamics, with unsustainable debt leading to capital flight that depreciates the exchange rate. And exchange rate depreciation in turn generates worsened debt dynamics because a significant portion of Brazil's debt is foreign currency denominated or indexed to the dollar.

This pattern has important policy implications. Too much attention has been focused on the exchange rate, and scarce foreign currency has been wasted defending it. Exchange rate weakness is a symptom of the problem, not the cause. The real problem is expectations of default created by high interest rates. This suggests that

Brazil's monetary authorities should mount a "bear squeeze" in Brazilian debt markets. Rather than giving Brazil $\$ 30$ billion in dribs and drabs, the IMF should give Brazil $\$ 30$ billion in one shot to buy up foreign currency denominated Brazilian debt. This would drive bond prices up and interest rates down. Contrastingly, giving the money in small chunks will result in it bleeding away without changing market expectations.

In addition, given the strength of the Real which has reduced the value of foreign currency indexed domestic bonds, the monetary authority should now buy these bonds. These purchases can in turn be sterilized by sales of pure domestic currency bonds. This measure would eliminate a major source of domestic financial fragility, whereby the Brazilian domestic debt burden can be whip-sawed by foreign exchange movements. These indexed bonds are a hang-over from mistaken earlier "nominal anchor" anti-inflation policies that purchased lower inflation at the cost of massively increased domestic financial fragility. 


\section{AN INTERNAL MONETARY STRATEGY \\ FOR BRAZIL'S INTERNAL DEBT PROBLEM}

A successful external strategy can bring down Brazil's external interest rate. Moreover, to the extent that investors feel more confident about Brazil, this will tend to appreciate the exchange rate, thereby reducing that part of the public debt that is indexed to the exchange rate. However, Brazil also needs to bring down domestic interest rates.

Falling yields on the external debt will make domestic assets more attractive, generating some portfolio substitution that will automatically drive down domestic interest rates. However, more may be needed. To this end, the central bank could lower its own short term interest rate, and it could also create a bear squeeze in domestic bond markets by buying up non-dollar indexed domestic currency denominated debt. Doing so would send a signal to the market that they expect bond prices to rise, and they also expect the exchange rate to rise - which is why they are not buying dollar indexed debt on which they would incur large capital losses.

How low the Brazilian monetary authorities should push the domestic interest is a judgment resting on a difficult trade-off. A higher domestic interest will tend to appreciate the exchange rate, thereby lowering the value of that part of the debt that is dollar indexed or denominated in dollars. Moreover, a higher exchange rate is also anti-inflationary. Balanced against this, a lower interest rate lowers interest payments on the domestic currency denominated debt, and it is also good for aggregate demand and the real economy.

Inflation is a second critical element in the calculus of domestic interest rate policy. It is critical that Brazil avoid higher inflation, both because of its negative impacts on working people and because of its negative impact on international financial markets. If these markets perceive that Brazilian inflation is about to take off, they will start selling Brazilian financial assets. This will depreciate the exchange rate and drive up the Brazil's borrowing rate in international markets. In effect, lack of attention to the inflationary impacts of expansionary domestic monetary policy rates could take back the space won by a successful external strategy.

Yet, Brazil also needs lower domestic rates to lower the interest burden on the $70 \%$ of its public debt that is denominated in domestic currency terms. In effect, Brazil is stuck in what can be termed "the highly indebted developing country" trilemma. This trilemma is illustrated in Figure 5.A. The manner in which debt is denominated means that Brazil must watch the exchange rate. It is also concerned about inflation, both because of its adverse internal effects and because of its adverse impact on the exchange rate. Finally, Brazil is concerned with the public finance burden of servicing the domestic public debt, and this makes it problematic to use high interest rates to combat incipient inflation. 


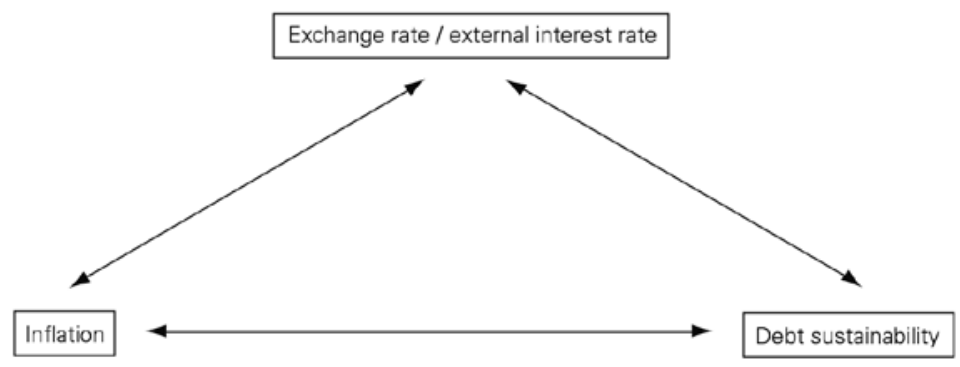

Can this trilemma be solved? The answer is yes. An appropriate external strategy that shifts Brazil to the low interest rate equilibrium can strengthen the exchange rate and lower the burden of the foreign currency denominated debt. Lower domestic interest rates can then lower the burden of the domestic currency debt. However, lowering domestic interest rates risks triggering domestic credit expansion and inflation. To prevent this outcome, Brazil's monetary authorities need to restrict domestic credit expansion. This last "unorthodox" element is missing in Brazil's current domestic monetary policy deliberations. In its absence, the trilemma cannot be resolved.

Given this Brazil should move to establish domestic credit creation controls. In particular, Brazil should consider imposing a system of asset based reserve requirements (ABRR) under which reserve requirement holdings are imposed on financial intermediary asset holdings. The full details and economic logic of ABRR are described in Palley (2000). In the current application, holdings of Brazilian government bonds would be zero-rated so as to keep down the interest rate. However, bank loans would carry positive reserve requirements so as to raise the cost of such loans and discourage excessive domestic credit creation. In this fashion, the inflation threat can be dealt with, and the trilemma is resolved as shown in Figure 5.B.

Figure 5.B: Policy mix for resolving the highly indebted developing country trilemma

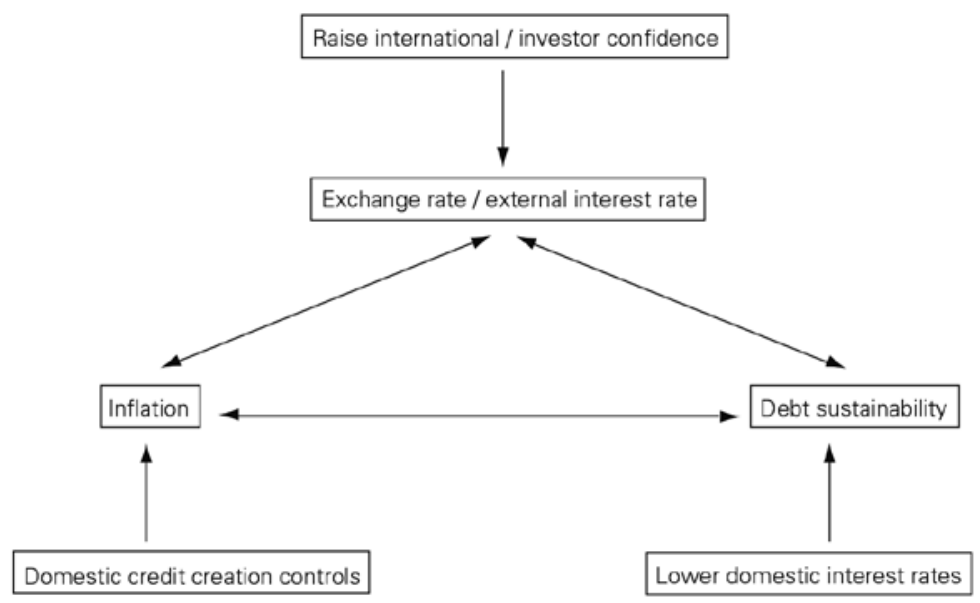


Finally, in addition to the above interest rate policy measures, Brazil should make two structural changes to its debt management policies. First, all new Brazilian debt and roll-overs of existing should include a call feature allowing for early redemption. This would send another clear signal that the authorities anticipate interest rates will come down. Second, Brazil should permanently abandon the practice of indexing its public debt to the exchange rate. This practice has some parallels with dollarization, and as with dollarization, it has created enormous financial fragility. In the absence of capital controls, Brazil cannot reliably control its exchange rate. This means that exchange rate indexing means makes the public debt susceptible to massive expansion from exchange rate depreciation, as has happened. Debt expansion has in turn created twin fears of default and inflation, leading to further exchange rate weakness. Put bluntly, Brazil cannot issue dollars, and it should therefore never tie its internal financial liability structure to the dollar.

\section{CONCLUSION: GROWTH WITH FINANCIAL STABILITY}

Brazil is currently trapped in a high interest rate "bad" equilibrium. The existing monetary policy mix has produced financial stability, but it is unlikely to produce growth. Moreover, because the debt dynamics implied by current interest rates are unsustainable, financial instability and the possibility of default will likely reappear if policy remains unchanged.

The policy program described in the current paper offers a plausible escape that can generate growth with financial stability. An external strategy aimed at pulling Brazil from the high interest rate equilibrium to the low interest rate equilibrium can lower the cost of foreign borrowing and appreciate the exchange rate. This will help restore debt sustainability, and also lower inflation. Appropriate domestic monetary policy can lower the domestic interest rate, thereby reducing the domestic debt service burden and solidifying debt sustainability. Finally, appropriately structured credit creation controls can guard against the inflationary consequence that may follow from lower domestic interest rates, thereby ensuring the viability of the external strategy.

So much remains to be done in Brazil regarding matters of income distribution and social policy. However, it will be hard to make progress on these issues until Brazil escapes the debt constraint on growth. Existing policy recommendations do not remove this constraint, and it is for this reason that the new government should embrace a new path for monetary policy.

\section{APPENDIX}

The appendix describes a model of multiple equilibrium in the market for Brazilian debt. Holders of Brazilian debt need to earn a risk adjusted expected re- 
turn equal to that which they could earn on other international investments, implying the following condition

$$
\text { (A.1) } 1+i^{*}+z=E(R)
$$

where $i^{*}=$ foreign interest rate, $\mathrm{z}=$ risk premium required for investing in Brazil, and $\mathrm{E}(\mathrm{R})=$ expected return to investments in Brazil. The expected return to Brazilian investments is given by

$+?-+?$ ?

$$
\text { (A.2) } \mathrm{E}(\mathrm{R})=\mathrm{p}(\mathrm{i}, \mathrm{d}(\mathrm{i}), \mathrm{D} / \mathrm{Y}, \mathrm{e}(\mathrm{i}, . .), . .) \mathrm{X}+[1-\mathrm{p}(\mathrm{i}, \mathrm{d}(\mathrm{i}), \mathrm{D} / \mathrm{Y}, \mathrm{e}(\mathrm{i}, . .) . .)][1+\mathrm{i}]
$$

where $\mathrm{p}()=$. probability of default, $\mathrm{X}=$ payment in default state, $\mathrm{i}=$ Brazilian real domestic interest rate, $\mathrm{e}=$ real exchange rate. An increase in e represents an appreciation of the Brazilian currency. The probability of default is such that $0 \leq \mathrm{p}$ $\leq 1$, and the default payment is such that $0 \leq \mathrm{X} \leq 1$. Signs above functional arguments represent assumed signs of partial derivatives. An increase in the Brazilian domestic interest rate increases the probability of default by increasing the government's debt service burden. An increase in the primary deficit has an ambiguous effect. On one hand there is a positive Keynesian aggregate demand effect, but on the other hand it adds to the government's indebtedness. The primary deficit may also be negatively impacted by higher interest rates, with the government being forced to cut back spending as rates rise. The impact of the real exchange rate on the probability of default is ambiguous. On one hand an appreciation reduces the debt burden since much Brazilian debt is indexed to the dollar, but on the other hand it reduces aggregate demand and economic activity by reducing net exports. Finally, the impact of the domestic interest rate on the exchange rate is ambiguous. The expected return function described by (A.2) is therefore highly non-linear, and can partake of a wave motion such as drawn in Figure 1.

The model is closed by adding a dynamic interest rate adjustment mechanism given by

$$
\text { (A.3) } \mathrm{di} / \mathrm{dt}=\mathrm{f}\left(1+\mathrm{i}^{*}+\mathrm{z}-\mathrm{E}(\mathrm{R})\right) \quad \mathrm{f}(0)=0, \mathrm{f}^{\prime}>0, \mathrm{f}^{\prime \prime}>0
$$

If the return on foreign assets exceeds the risk adjusted expected return on Brazilian assets, the Brazilian domestic interest rate rises as agents sell Brazilian assets to buy foreign assets. Equation (A.3) therefore ensures that if $E(R)>1+i^{*}+z$ investors buy Brazilian debt driving up its price and lowering its interest rate. The reverse holds if $E(R)>1+i^{*}+z$. However, whether $E(R)$ converges to $1+i^{*}+z$ depends on how the expected return responds to changes in the domestic interest rate.

Guaranteeing the size of the payment in the default state, as has been suggested by George Soros (200), is equivalent to increasing the value of X. As illustrated in Figure 4, this shifts up the $\mathrm{E}(\mathrm{R})$ function. If the increase is sufficiently large it can enable escape from the bad equilibrium at $\mathrm{C}$ to the good equilibrium at $\mathrm{A}$.

A second proposal by George Soros is that G-7 central banks accept Brazilian government paper at their discount windows (On Globalization, p. 136). This would have the effect of increasing the perceived liquidity of Brazilian paper to international investors because they would always be able to use it as collateral at 
pre-agreed prices with center country central banks. In effect, such a measure would also shift up the $\mathrm{E}(\mathrm{R})$ function.

\section{REFERENCES}

LERRICK, A., and MELTZER, A.H., "Beyond IMFF Bailouts: Default Without Disruption”, On the Issues, American Enterprise Institute, Washington, DC, May 2001.

International Monetary Fund, "Brazil — Letter of Intent: Memorandum of Economic and Financial Policies, and Technical Memorandum of Understanding”, June 5, 2002.

PALLEY, T.I., "Soros on International Capital Markets and Developing Economies: Multiple Equilibria and the Role of Policy", paper presented at a conference on "Reforming the Reforms," Brazil Center for Policy Studies, Rio de Janeiro, Brazil, November 29, 2002.

"Stabilizing Finance: The Case for Asset Based Reserve Requirements", Financial Markets and Society, Financial Markets Center, VA, USA, August 2000 (available at www.fmcenter.org).

SOROS, G., Remarks delivered at the Institute for International Economics, Washington, DC, September 30, 2002.

"Don't Blame Brazil", Financial Times, August 13, 2002. , On Globalization, New York: Public Affairs, 2002. 